\title{
Hemosiderin. A new marker for sentinel lymph node identification ${ }^{1}$
}

\author{
Hemossiderina. Um novo marcador para identificação do linfonodo sentinela
}

\author{
Luiz Gonzaga Porto PinheiroI, Renato Santos de Oliveira Filho"I, Paulo Henrique Diógenes Vasques ${ }^{\text {III }}$, Pedro Henrique de Oliveira \\ Filgueira $^{I V}$, Douglas Henning Pinheiro Aragão ${ }^{\mathrm{IV}}$, Pedro Macedo Esmeraldo Barbosa ${ }^{\mathrm{IV}}$, Hugo Enrique Orsini Beserrav ${ }^{\mathrm{V}}$, Raissa \\ Vasconcelos Cavalcante ${ }^{V}$
}

\author{
${ }^{\mathrm{I}} \mathrm{PhD}$, Associate Professor, Department of Surgery, Faculty of Medicine, UFC, Fortaleza - CE, Brazil. \\ ${ }^{\text {II }} \mathrm{PhD}$, Affiliate Professor, Division Plastic Surgery, Department of Surgery, Federal University of Sao Paulo (UNIFESP), Brazil. \\ III Fellow Master degree, Postgraduate Program, Department of Surgery, UFC, Fortaleza - CE, Brazil. \\ IV Graduate student, Medicine Faculty, UFC, Fortaleza - CE, Brazil. \\ ${ }^{v}$ Graduate student, Veterinary Faculty, State University of Ceara (UECE), Brazil.
}

\begin{abstract}
Purpose: To evaluate and present our initial results of a new marker (hemosiderin) for mammary sentinel lymph node identification in an experimental model. Methods: Skins mapped like a lymphatic duct draining to the axilla in patients submitted to breast biopsy, in our mastology service, stimulated us to try it in an animal model (female dogs). Our theory was that some blood derivate (hemosiderin) was captured by macrophages and accessed the lymphatic ducts in direction to the axilla. Six female dogs of no defined race were studied. We injected $0,2 \mathrm{ml}$ of technetium on both superior mammary glands. After ten minutes, a 2,5 $\mathrm{ml}$ solution of hemolized blood (hemosiderin) from the own animal was injected in the subareolar lymphatic plexus on the left superior mammary gland and 2,5 ml of patent blue concomitantly and equally on the contralateral gland. Ten minutes after, incisions on both axilas were made to search, through the lymphatic mapping and a gamma probe, the sentinel lymph nodes. Results: Seven brown sentinel lymph nodes were indentified and also radiomarked on the left axilla. Six blue sentinel lymph nodes were identified and also radiomarked on the right axilla. Conclusion: Preliminary studies of a potential new dye for sentinel lymph node identification are presented. It may be the change of the current use of the blue dyes and their severe side-effects on patients submitted to sentinel lymph node biopsies.
\end{abstract}

Key words: Breast Neoplasms. Sentinel Lymph Node Biopsy. Hemosiderin.

\section{RESUMO}

Objetivo: Avaliar e apresentar resultados preliminares de um novo marcador (hemossiderina) para a identificação de linfonodos sentinela mamários em um modelo experimental. Métodos: Durante acompanhamento de dois casos de biópsias excisionais de tumores da mama, no nosso serviço de mastologia, observou-se trajeto pigmentado no quadrante inferior externo daquelas mamas, sugerindo ser marcação cutânea do ducto de drenagem linfática a partir da papila mamária em direção a axila homolateral. Levantamos a hipótese que um derivado sanguíneo (hemossiderina) foi capturado por macrófagos obtendo acesso aos ductos linfáticos em direção à axila. Seis cadelas sem raça definida foram estudadas. Injeção de $0,2 \mathrm{ml}$ de tecnécio foi realizada em ambas as mamas superiores. Após 10 minutos, uma solução de 2,5 ml de sangue hemolizado (hemossiderina) do próprio animal foi injetado no plexo linfático subpapilar da mama esquerda e 2,5 ml de azul patente na mama contralateral concomitantemente e igualmente. Após mais 10 minutos, incisões axilares foram realizadas para a procura, pela coloração e com um gama probe, dos linfonodos sentinela. Resultados: Sete linfonodos sentinela castanhos e radiomarcados foram identificados na axila esquerda. Seis linfonodos sentinela azuis e radiomarcados foram identificados na axila direita. Conclusão: São apresentados estudos preliminares de um potencial novo marcador para identificação do linfonodo sentinela. Este poderá mudar o uso dos corantes vitais e de seus efeitos adversos em pacientes submetidos à biópsia do linfonodo sentinela.

Descritores: Neoplasias da Mama. Biópsia de Linfonodo Sentinela. Hemossiderina.

${ }^{1}$ Research performed at Experimental Animal Laboratory, Department of Surgery, Faculty of Medicine, Federal University of Ceara (UFC), Fortaleza, Brazil.

\section{Introduction}

The incidence of female breast cancer has increased $0.5 \%$ since the year 2000 , as reported by the International Agency Research on Cancer. This number is greater in developing countries due to the increase in life expectancy and change in behavior resulting in increased exposure to risk factors.
Lymph node staging is an early event carried out during initial patient evaluation in developed countries. Some $20 \%$ to $30 \%$ of all cases are diagnosed quite early (in situ lesions) with negative axillary nodes in $79 \%$ of the patients at this stage ${ }^{1}$. These values are somewhat different in developing countries where more than $50 \%$ of the cases are diagnosed at advanced stages of the disease. Late stages (III and IV) of breast cancer are seen in $60 \%$ of women 
who seek medical attention at the Maternidade-Escola (Federal University of Ceara) Breast Unit. Lack of adequate surveillance programs, the reduced number of specialists and the small number of educational programs may account for these numbers.

Increased survival rates have been reported lately. According to Parkin ${ }^{2}$, the overall survival rate is $91 \%$ after the first year and $65 \%$ after five years in Europe. These values increase to $96.8 \%$ after the first year in the United States. As primary prevention of breast cancer is not available as yet, early detection and treatment in the initial phase of the disease are, therefore, the most important measures for its control ${ }^{3}$.

Available diagnostic methods include mammography, breast ultrassonography, sentinel lymph node biopsy, and fine-needle aspiration biopsy among others ${ }^{4,5}$. With the definition of the sentinel lymph node as the first one which receives the drainage of the tumoral area ${ }^{6}$, it was possible to ensure means for the proper staging of the illness and the therapeutic approach establishing less invasive surgery techniques.

Currently, it is admitted that the presence of metastatic lymph nodes is the main predictor factor for prognosis of the breast malignant neoplasia course and subsequent therapeutic program. Lymph nodes are also valuable for staging breast cancer. In the recent past dissection of the axillary lymph nodes was required for this matter, resulting in a series of additional complications ${ }^{7}$.
The principles of the sentinel lymph node were first used by Cabanas (1973) in penis cancer. Morton et al. ${ }^{8}$ used this principles on the identification of melanoma metastasis. He used Patent blue dye. Giuliano et al. ${ }^{9}$ described its use for the breast cancer, also using the vital blue dye for lymphatic mapping and then, Krag et $a l .{ }^{10}$ additionally used a radioguided model with a gamma probe increasing the accuracy on the identification of the sentinel lymph node.

The results of the researches on breast sentinel lymph node are encouraging, although there are some methods which are controversial ${ }^{11}$. One of these is the vital blue dye use for the lymphatic mapping which may cause severe hypersensitivity reactions on patients ${ }^{12}$. Other dyes are used, as methylene blue which may also cause serious reactions, including skin and fat necrosis in the site of injection ${ }^{13}$.

During the management of two patients submitted to breast biopsy in our service, we observed their skin mapped as the lymphatic ducts draining to axillary lymph nodes. This observation stimulated us to try an animal model which was described for our group. Our theory was that some blood derivate (hemosiderin) was captured by macrophages and accessed the lymphatic duct in direction to the axilla (Figure 1). For these reasons, the purpose of this paper is to present our initial results of a new marker for sentinel lymph node identification.

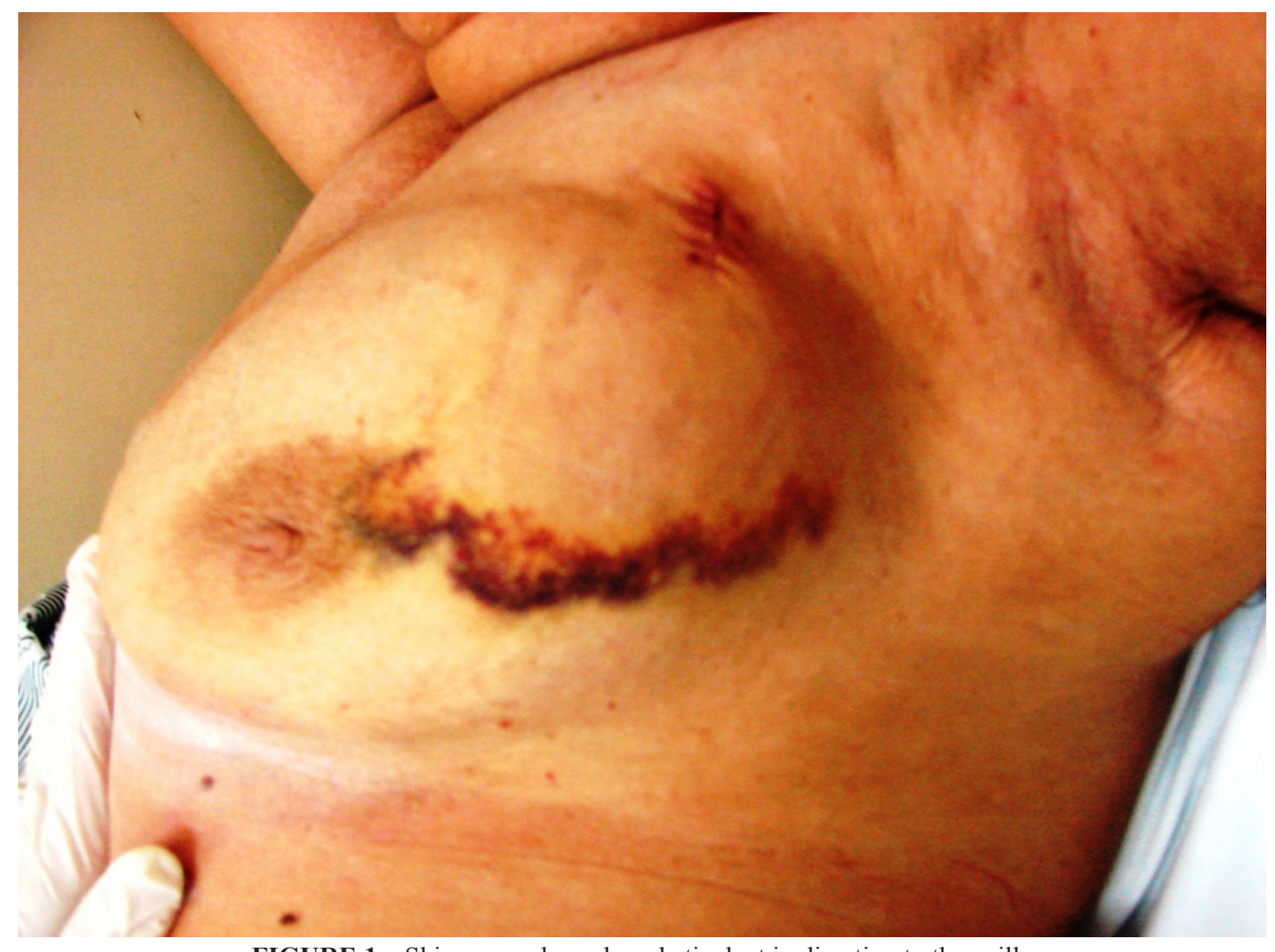

FIGURE 1 - Skin mapped as a lymphatic duct in direction to the axilla 


\section{Methods}

Prospective experimental surgical study approved by the Ethic Commission in Animal Research of our university (UFC). It took place in the experimental surgery laboratory Prof. Saul Goldenberg in order to evaluate the use of a blood derivate (hemosiderin) on mammary sentinel lymph node mapping in female dogs.

Six female dogs of no defined race, with $10 \mathrm{~kg}$ as mean weight, were given by the zoonoses control center of Fortaleza to be studied. These animals were part of a group programmed for sacrifice as they may be infected by diseases which affect men. The animals, after proper immobilization, were anesthetized with an intramuscular application of ketamine $(05-10 \mathrm{mg} / \mathrm{kg})$ immediately before the experiment.

For the hemoglobin use (hemosiderin precursor), $10 \mathrm{ml}$ of blood were obtained from the left internal jugular vein of the animal to be studied. From that blood, $8 \mathrm{ml}$ were stored in 2 (two) tubes with an anticoagulant solution (EDTA), $4 \mathrm{ml}$ in each tube.

These tubes were placed symmetrically in a centrifuge for 5 (five) minutes at $3800 \mathrm{rpm}$. Then, in each tube, an interface was observed; the upper phase is the plasma which was extracted with a pipette. To the rest of the volume of each tube, equal volume in $\mathrm{mL}$ of $\mathrm{NaCl} 0,9 \%$ was added, in order to double the final volume. After manual homogenization, the tubes were replaced in the centrifuge for more 5 (five) minutes at 3800 RPM. A new interface was noted and the upper phase (a serum solution) was once again extracted. With these steps erythrocyte concentrates were obtained in each tube.

Once again, to the rest of the volume of each tube (erythrocyte concentrates), equal volume of bidistilled water was added, in order to double the final volume. Vigorous homogenization was performed manually, causing hemolysis by the osmolarity difference. The tubes were replaced in the centrifuge for more 3 (three) minutes to confirm the hemolysis. If there was no interface after this last centrifuging, the hemolysis was confirmed. The volume of $2,5 \mathrm{ml}$ of one tube (hemosiderin) was taken to be used on the lymph node research.

The radioactive tracer (technetium $99 \mathrm{~m}$ ), the processed blood and the patent blue (Guerbert V 2,5\%) were injected in the mammary subareolar lymphatic plexus. Following with the surgical procedure, the two first mammary pairs (superior) of the female dog were defined where $0,2 \mathrm{ml}$ of the radioactive tracer were injected in each mammary gland. After 10 (ten) minutes, $2,5 \mathrm{ml}$ of patent blue were injected in the right mammary gland and $2,5 \mathrm{ml}$ of the processed blood were injected in the left mammary gland, at the same time. After more 10 (ten) minutes, 5 (five) $\mathrm{cm}$ incisions were made in both axillas for the sentinel lymph node identification by its color and with the guide of a gamma-detecting probe.

When the surgery was finished, the euthanasia of the animal was performed injecting intravenously, all at once, diazepam $(0,5 \mathrm{mg} / \mathrm{kg})$, acepromazine $(0,1 \mathrm{mg} / \mathrm{kg})$ and ketamine $(5-10 \mathrm{mg} / \mathrm{kg}$ ) and, after 5 (five) minutes, a $20 \mathrm{ml}$ solution of potassium chloride $10 \%$.

\section{Preliminary results}

Six experiments were performed according to the methodology described and showed the following results. In all animals, at least one mammary sentinel lymph node, each one colored and radiomarked, was identified from each axilla. In the total, 13 (thirteen) mammary sentinel lymph nodes colored and radiomarked were identified from all axillas (Table 1).

TABLE 1 - Number of mammary sentinel lymph nodes colored and radiomarked found in each axilla by animal

\begin{tabular}{lll}
\hline Animal & $\begin{array}{l}\text { Right mammary gland } \\
\text { (patent blue }+ \text { tecnecium) }\end{array}$ & $\begin{array}{l}\text { Left mammary gland } \\
\text { (hemosiderin }+ \text { tecnecium) }\end{array}$ \\
\hline $\mathbf{1}$ & 1 lymph node & 1 lymph node \\
\hline $\mathbf{2}$ & 1 lymph node & 1 lymph node \\
\hline $\mathbf{3}$ & 1 lymph node & 1 lymph node \\
\hline $\mathbf{4}$ & 1 lymph node & 1 lymph node \\
\hline $\mathbf{5}$ & 1 lymph node & 1 lymph node \\
\hline $\mathbf{6}$ & 1 lymph node & 2 lymph nodes \\
\hline
\end{tabular}

All the sentinel lymph nodes found in the right axillas were radiomarked and had a blue color. All the sentinel lymph nodes found in the left axillas were radiomarked and had a brown color (Figure 2). We observed that both colors were different from those of control lymph nodes (Figure 3). There were no problems or difficulties on finding mammary sentinel lymph nodes in the axillas of the female dogs with these techniques. 


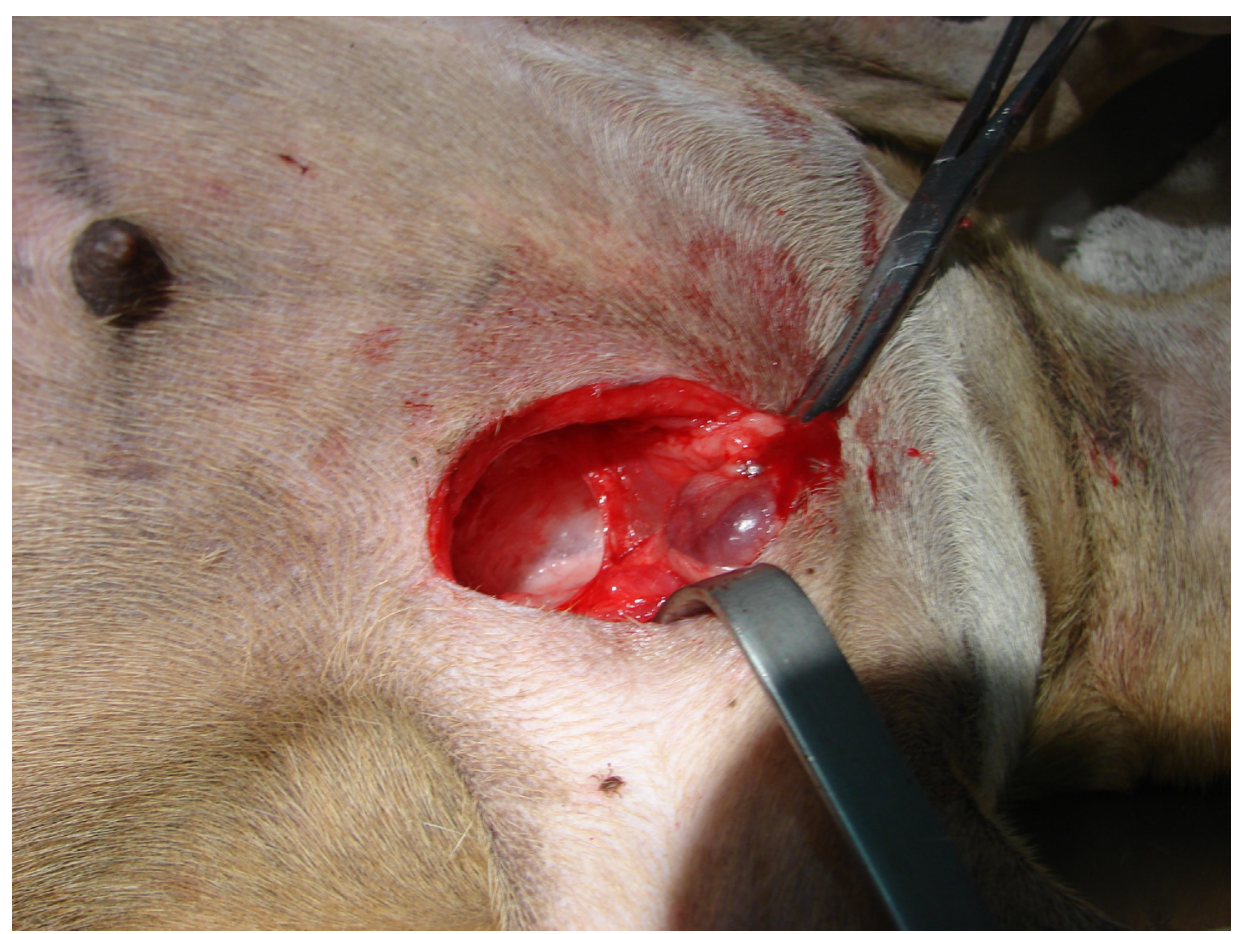

FIGURE 2 - Sentinel lymph node marked with hemosiderin in vivo

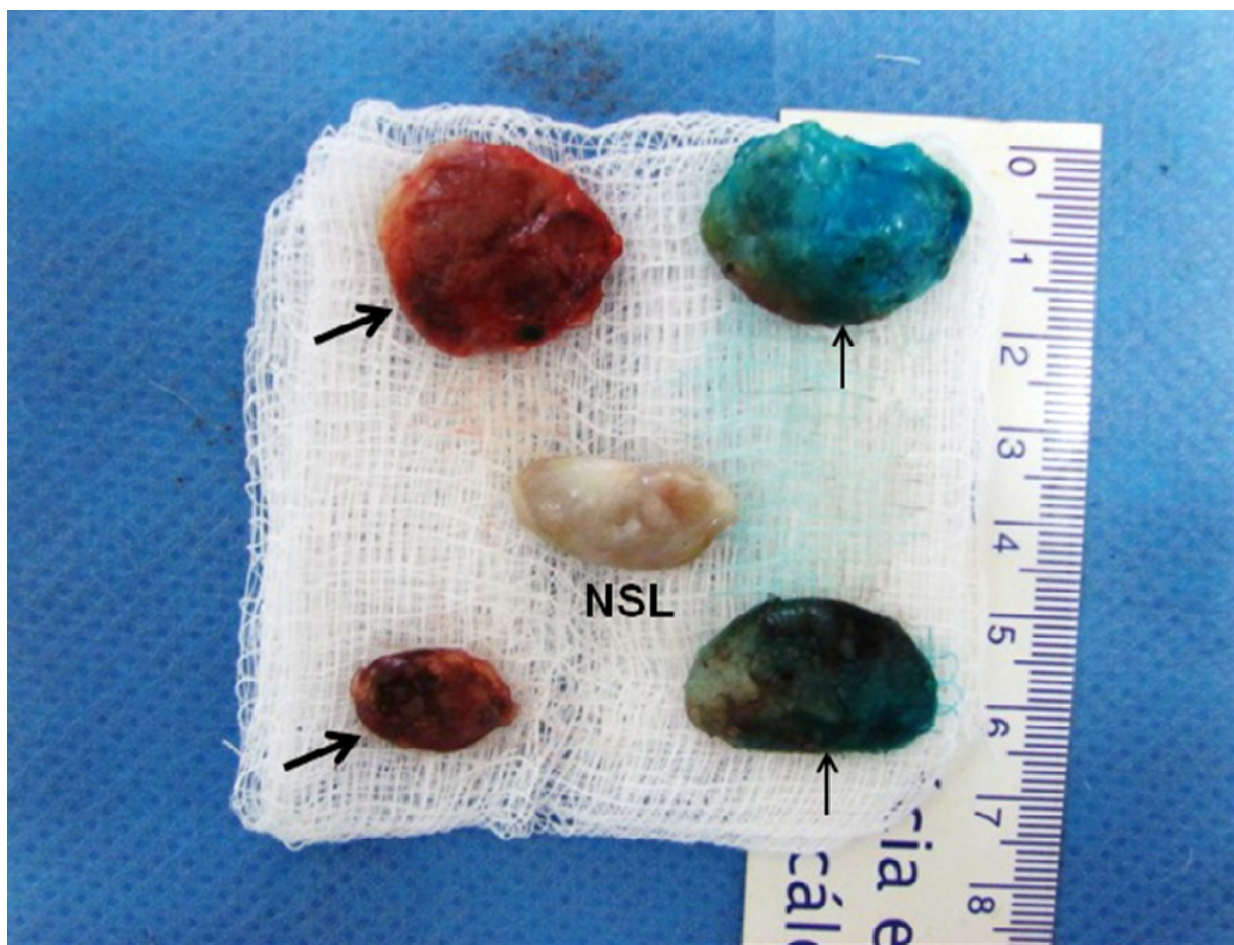

FIGURE 3 - Sentinel lymph nodes marked with hemosiderin at left (bold arrows) and with patent blue at right (thin arrows). NSL $=$ Non-sentinel lymph node.

\section{Discussion}

Sleth ${ }^{14}$, while discussing, in his work, the annual rise on the incidence of adverse reactions to blue dyes during sentinel lymph node biopsies, the clearly quantifiable allergic risks and the continuous evolution of the sentinel lymph node study in other tumors, asked if it was not the time to change the dye.

Nowadays, reactions to vital dyes are being more frequently reported due to its increased use in lymphatic mappings and in sentinel lymph node biopsies in patients with breast cancer and other malignancies ${ }^{12,15}$. Cases and meta-analysis of anaphylactic reactions are described due to the use of blue dyes in sentinel lymph node identification. The incidence of anaphylactic reactions to isosulfan blue or patent blue vary from $0,6 \%$ to $2,7 \%$ in patients submitted to sentinel lymph node biopsy and must be known by the surgeon and the anesthesiologist ${ }^{16}$.

Mertes et al. ${ }^{15}$ reported 14 clinical cases of anaphylaxis induced by dyes during the years 2004 and 2006 in four different allergoanesthesia french centers. All patients suffered hypersensitive reactions to patent blue $\mathrm{V}$ during sentinel lymph node biopsy due to breast cancer. In this study, $43 \%$ of patients suffered life-threatening reactions (cardiovascular collapse, tachycardia or bradycardia, arrhythmias and severe bronchospasm) and $64 \%$ of these patients required prolonged continuous epinephrine infusion and transference to an intensive care unit. The authors recommended the use of dermatologic tests for these markers before surgery.

Wohrl et al. ${ }^{17}$ described a near-fatal case of anaphylaxis due to the patent blue $\mathrm{V}$ dye in sentinel lymph node identification. A patient with melanoma suffered cardiac arrest for 10 minutes and required mechanic cardio-pulmonary reanimation measures after the intradermal injection of this dye.

The preliminary results of our experimental work showed that the blood derivate (hemosiderin) was capable of being used along with the radiomarker (technetium 99m) and coloring wonderfully the sentinel lymph node of female dogs. 
The use of the blood derivate (hemosiderin) with the radiomarker also showed equal results comparing the use of the patent blue with the radiomarker in identifying the mammary sentinel lymph nodes of the female dog because they were always found in both axillas.

The hemosiderin, a blood-derived marker, theoretically does not cause side effects as allergic reactions. Besides, it may decrease personal and healthcare spendings, reduce the morbidity of the procedure and the emotional suffering, along with other indirect vantages.

\section{Conclusion}

Preliminary studies of a potential new dye for sentinel lymph node identification are presented. It may be the change of the current use of the blue dyes and their severe side-effects on patients submitted to sentinel lymph node biopsies.

\section{References}

1. Holland JF, Frei E, Kufe DW, Bast RC. Principles of medical oncology. 6ed. Philadelphia: Saunders; 2001.

2. Parkin DM, Bray FI, Devesa SS. Cancer burden in the year 2000. The global picture. Eur J Cancer. 2001;37:64-6.

3. Instituto Nacional do Câncer. Estimativas da incidência e mortalidade por câncer no Brasil em 2008. [cited 2009 April 12]. Available from URL: http://www.inca.gov.br/estimativa/2008/index.asp

4. Moore MP, Kinne DW. Is axillary lymph node dissection necessary in the routine management of breast cancer? Yes. Important Adv Oncol. $1996 ; 12: 245-50$

5. Morton DL, Ollila DW. Critical review of the sentinel node hypothesis. Surgery. 1999;126:815-9.

6. Cabanas RM. An approach for the treatment of penile carcinoma. Cancer. 1977;39(2):456-66.
7. Veronesi U, Paganelli G, Niale G, Galimberti V, Luini A, Zurrida S, Robertson C, Sacchini V, Veronesi P, Orvieto E, De Cicco C, Intra M, Tosi G, Scarpa D. Sentinel lymph node biopsy and axillary dissection in breast cancer: results in a large series. J Natl Cancer Inst. 1999;91:368-73.

8. Morton DL, Wen DR, Wong JH, Economou JS, Cagle LA, Storm FK, Foshag LJ, Cochran AJ. Technical details of intraoperative lymphatic mapping for early stage melanoma. Arch Surg. 1992;127:392-9.

9. Giuliano AE, Kirgan DM, Guenther JM, Morton DL. Lymphatic mapping and sentinel lymphadenectomy for breast cancer. Ann Surg. 1994;220:391-401.

10. Krag DN, Weaver DL, Alex JC, Fairbank JT. Surgical resection and radiolocalization of the sentinel lymph node in breast cancer using a gamma probe. Surg Oncol. 1993;2:335-9.

11. Pinheiro LGP, Moraes MO, Soares AH, Lopes AJT, Naguére MASP, Gondim FAL, Brandão CB, Nascimento DCH, Soares JPH, Silva JMM. Estudo Experimental de linfonodo sentinela na mama da cadela com azul patente e tecnécio Tc99. Acta Cir Bras. 2003;18(6):545-52.

12. Mertes PM, Malinovsky JM, Mouton-Faivre C, Bonnet-Boyer MC, Benhaijoub A, Lavaud F, Valfrey J, O'Brien J, Pirat P, Lalourcey L, Demoly P. Anaphylaxis to dyes during the perioperative period: reports of 14 clinical cases. J Allergy Clin Immunol. 2008; 122:348-52.

13. Salhab M, Al Sarakbi W, Mokbel K. Skin and fat necrosis of the breast following methylene blue dye injection for sentinel node biopsy in a patient with breast cancer. Int Semin Surg Oncol. 2005;2:26.

14. Sleth JC. Un accident anaphylactoïde imputé au bleu patenté. Faut-il changer de colorant? Ann Fr Anesth Reanim. 2008;27:515.

15. Mulan MH, Deacock SJ, Quiney NF, Kissin MW. Anaphylaxis to patent blue dye during sentinel lymph node biopsy for breast cancer. Eur J Surg Oncol. 2001;27:218-9.

16. Scherer K, Studer W, Figueiredo V, Bircher AJ. Anaphylaxis to isosulfan blue and cross-reactivity to patent blue $\mathrm{V}$ : case report and review of the nomenclature of vital blue dyes. Ann Allergy Asthma Immunol. 2006;96:497-500.

17. Wohrl S, Focke M, Hinterhuber G, Stingl G, Binder M. Near-fatal anaphylaxis to patent blue V. Br J Dermatol. 2004;150:1037-8.

Conflict of interest: none Financial source: none

\section{Correspondence:}

Luiz Gonzaga Porto Pinheiro

Departamento de Cirurgia

Rua Prof. Costa Mendes 1608/ 3o andar

60430-140 Fortaleza-CE Brazil

Phone: (55 85)3366-8063

Fax: (55 85)3283-7851

luizgporto@uol.com.br

Received: April 14, 2009

Review: June 10, 2009

Accepted: July 15, 2009

\section{How to cite this article}

Pinheiro LGP, Oliveira Filho RS, Vasques PHD, Filgueira PHO, Aragão DHP, Barbosa PME, Beserra HEO, Cavalcante RV. Hemosiderin. A new marker for sentinel lymph node identification. Acta Cir Bras. [serial on the Internet] 2009 Nov-Dec;24(6). Available from URL: http://www.scielo.br/acb 